\title{
Influence of maturity on alfalfa hay nutritional fractions and indigestible fiber content
}

\author{
A. Palmonari, ${ }^{1}$ M. Fustini, G. Canestrari, E. Grilli, and A. Formigoni \\ Department Of Veterinary Medicine, Università di Bologna, 40084 Bologna, Italy
}

\section{ABSTRACT}

This study focused on changes in fibrous and protein fractions, changes in fiber digestibility and amount of indigestible neutral detergent fiber (NDF) as a consequence of increased maturity in alfalfa. A total area of $720 \mathrm{~m}^{2}$ was divided in 18 blocks randomly assigned to 3 treatments, differing in cutting intervals. Treatment 1 was harvested with a 21-d cutting schedule, at a prebloom stage; treatment 2 with a $28-\mathrm{d}$ schedule, at about first-bloom stage; whereas a full bloom was observed in treatment 3, harvested with a 35-d cutting schedule. Treatments were replicated 4 times through the springsummer period for 2 subsequent years, 2011 and 2012. Statistical differences were observed for crude protein [treatment 1: $20.8 \%$, treatment 2: $17.3 \%$, and treatment 3: $17.0 \%$; standard error of the mean $(\mathrm{SEM})=$ 0.83], soluble protein, and nonprotein nitrogen among treatments on a dry matter basis. Similar results were observed for acid detergent lignin $(6.3,6.9$, and $7.3 \%$, respectively; SEM $=0.39$ ), lower in treatment 1 compared with others, and in vitro NDF digestibility at 24 or $240 \mathrm{~h}$. Indigestible NDF at $240 \mathrm{~h}$ resulted in lower values for treatment 1 compared with treatments 2 and $3(15.5,17.2$, and $18.3 \%$, respectively; $\mathrm{SEM}=1.54)$. Moreover, the indigestible NDF:acid detergent lignin ratio varied numerically but not statistically among treatments, being as much as $9 \%$ greater than the 2.4 fixed value applied for rate of digestion calculation and Cornell Net Carbohydrate Protein System (Cornell University, Ithaca, NY)-based model equations. Assuming the diet composition remained unchanged, treatment 3 (35-d cutting interval) would be expected to yield $1.4 \mathrm{~kg}$ less milk per day based on energy supply, and $2.8 \mathrm{~kg}$ less milk daily based on protein supply than treatment 1.

Key words: alfalfa, maturity, indigestible neutral detergent fiber

Received March 11, 2014.

Accepted August 6, 2014.

${ }^{1}$ Corresponding author: alberto.palmonari2@unibo.it

\section{INTRODUCTION}

Alfalfa hay, one of the most utilized forages in Italy, is particularly important in the areas of Po Valley involved in production of Parmigiano Reggiano cheese, where silage feeding is prohibited to prevent environmental clostridia contamination (Parmigiano-Reggiano Cheese Consortium, 2011) in milk. Thus, hay is the main source of forages for these dairy rations. In northern Italy, 4 or more cuttings of alfalfa can be harvested annually. Numerous studies have shown that forage quality is affected by growth stage (Nordkvist and Âman, 1986; Yu et al., 2003), species, cultivar (Griffin et al., 1994), and growing conditions (e.g., rainfall, temperature, and soil composition; Minson and McLeod, 1970; Cox et al., 1994; Mathison et al., 1996).

Alfalfa (Medicago sativa L.) is a perennial legume with a unique anatomy comprising relatively distinct protein-containing leaves and fibrous stems. Maturity influences both fiber digestibility and protein fractions in alfalfa through increasing the leaf:stem ratio and increasing lignification of stems, which, in turn, alters fiber digestibility (Weir et al., 1960; Yu et al., 2003). Lignin negatively affects forage fiber digestion degree and rate (Albrecht et al., 1987; Van Soest, 1994; Sewalt et al., 1997b), the extent of which depends on its concentration, composition (Buxton and Russell, 1988; Buxton and Brasche, 1991), tissue distribution (Akin, 1989), and phenolic functionality (Sewalt et al., 1997a). Lignin, due to its peculiar phenolic composition, cannot be digested in anaerobic environments, and is able to reduce the proportion of potentially digestible fiber fraction in forages (Jung and Allen, 1995), representing the indigestible NDF (iNDF). In Cornell Net Carbohydrate Protein System (CNCPS; Cornell University, Ithaca, NY; Sniffen et al., 1992)-based models, such as Cornell-Penn-Miner (CPM) Dairy software [version 3.0.10; Cornell University (Ithaca, NY), University of Pennsylvania (Philadelphia), The William H. Miner Agricultural Research Institute (Chazy, NY), and the University of Maryland (College Park); Boston et al., 2000], the iNDF is calculated as ADL times a fixed value (2.4), without differentiation among forages, nor between early cut or late cut (Sniffen et al., 1992; Van 
Soest et al., 2005). Moreover, iNDF is essential in the rate of digestion $(\mathrm{kD})$ equations, in order to calculate the amount of NDF that could be digested and its rate. The objective of this study was to determine the influence of maturity and cutting treatment on alfalfa chemical composition and, in particular, in vitro fiber digestibility and the iNDF fraction.

\section{MATERIALS AND METHODS}

\section{Experimental Design}

This study was conducted using a native alfalfa variety, called Romagnola, sown in 2007 in an experimental plot close to the Department of Veterinary Medicine of Bologna University (Bologna, Italy). No insecticides or herbicides were applied, and no soil fertilization or irrigation was conducted. The field had a clay soil with medium porosity, and its relative average humidity and $\mathrm{pH}$ were recorded at the beginning of each trial.

A total area of $720 \mathrm{~m}^{2}$ was divided in 18 plots randomly assigned to 3 treatments, differing in cutting intervals. Treatment 1 (PreB-21dd) involved harvesting every $21 \mathrm{~d}$ at about prebloom, treatment 2 (FrsB-28dd) every $28 \mathrm{~d}$ at about first bloom, and 35 $\mathrm{d}$ at about full bloom for treatment 3 (FulB-35dd). Treatments were replicated 4 times through the springsummer period in 2 subsequent years (2011 and 2012). All plots were cut at the beginning of the third week of April to obtain a common starting date for all treatments. Plots were harvested approximately at $0900 \mathrm{~h}$, 7 to $10 \mathrm{~cm}$ above the soil to aid plants regrowth and avoid soil contamination.

\section{Chemical Analysis, In Vitro Fermentation, and Rationing}

Immediately after harvesting, a representative (1.0$\mathrm{kg}$ ) sample, randomly obtained by hand from each block of each treatment, was collected and immediately dried in a forced-air oven at $65^{\circ} \mathrm{C}$ for $48 \mathrm{~h}$ to determine DM content. From each block, forage was sampled and dried following the same procedure as above. Once dried, samples were ground through a 1-mm screen in a Cyclone mill (model SM100; Retsch GmbH, Haan, Germany). The samples were analyzed for CP (AOAC, 1990; methods 976.06 and 984.13), NPN, soluble protein, neutral detergent-insoluble protein, acid detergentinsoluble protein (Licitra et al., 1996), amylase-treated NDF (Mertens, 2002) with addition of sodium sulfite, ADF (AOAC, 1990; method 973.18), and ADL (AOAC, 1990; method 973.18). Briefly, the ADF residue was suspended within the crucible in $40 \mathrm{~mL}$ of sulfuric acid (72\% concentration) for $3 \mathrm{~h}$. Residues were then washed with boiling water and dried overnight at $65^{\circ} \mathrm{C}$. Once weighed, crucibles were placed in a muffle furnace for $4 \mathrm{~h}$ at $490^{\circ} \mathrm{C}$ to incinerate the residue. Ash content was then subtracted from the initial weight to calculate the ADL content. In vitro NDF digestibility at 24 and 240 $\mathrm{h}$ was determined using the Tilley and Terry modified technique (Tilley and Terry, 1963; Goering and Van Soest, 1970; Robertson and Van Soest, 1981). Rumen fluid was collected by sampling rumens of 2 lactating cows (fed a hay-based diet; Table 1; milk production = $31.8 \pm 2.3 \mathrm{~kg} / \mathrm{d} ; \mathrm{DIM}=274 \pm 2$ ), using an esophageal tube, mixed and placed in a thermostatic bottle. Under insufflation of $\mathrm{O}_{2}$-free $\mathrm{CO}_{2}$, liquor was filtered through 4 layers of cheesecloth. A $10-\mathrm{mL}$ volume of rumen fluid was inoculated in each Erlenmeyer flask already placed in a heated water bath under $\mathrm{CO}_{2}$-positive pressure to ensure anaerobiosis. Flasks contained $40 \mathrm{~mL}$ of the solutions described by Goering and Van Soest (1970) and $0.50 \mathrm{~g}$ of sample. Each sample was analyzed in triplicate in 2 different in vitro fermentations. For both, sample preparation and diet was the same as for the donor cows. At the end of the fermentation, the content of each flask was analyzed to determine NDF content of the residue. Digestibility was calculated as the difference between 100 and 100 times the residual NDF:initial NDF ratio. Other fermentations were conducted for $240 \mathrm{~h}$ to estimate the amount of iNDF. We based our choice about fermentation length on previous studies indicating $240 \mathrm{~h}$ as the maximum extent of fiber digestion in an anaerobic environment (Chandler, 1980; Van Soest, 1994). For these fermentations, both rumen fluid and buffer were reinoculated after $120 \mathrm{~h}$ to preserve the microbial activity during the whole process. A final volume of $100 \mathrm{~mL}$, containing $0.50 \mathrm{~g}$ of sample, was treated for NDF content determination as described above.

To predict $\mathrm{RDP}, \mathrm{NE}_{\mathrm{L}}$, and possible milk production due to MP and ME, each hay corresponding to the 3 treatments was used as the main forage source in CPM, a dairy ration software based on the CNCPS. Diet compositions are listed in Table 2. Cows were assumed to weigh $620 \mathrm{~kg}$, have a BCS of 3.00, be in second lactation, be at 120 DIM, and produce $35.00 \mathrm{~kg}$ of milk/d with $3.60 \%$ fat and $3.30 \%$ total protein concentration.

\section{Environmental Conditions}

During the trial, the total amounts of rainfall and temperatures were recorded daily and results were summarized for each cutting schedule treatment. The weather station was located within $1,000 \mathrm{~m}$ of the experimental area. Data were collected from the official website of the Environmental Protection Regional Agency (ARPA Emilia Romagna, Bologna, Italy). 
PALMONARI ET AL.

Table 3. Descriptive environmental data recorded during the trial

\begin{tabular}{|c|c|c|c|c|c|c|}
\hline \multirow[b]{2}{*}{ Measure } & \multicolumn{3}{|c|}{ Treatment $^{1}$} & \multicolumn{2}{|c|}{ Year } & \multirow[b]{2}{*}{ SEM } \\
\hline & PreB-21dd & FrsB-28dd & FulB-35dd & 2011 & 2012 & \\
\hline \multicolumn{7}{|l|}{ Rainfall, mm } \\
\hline First cut & 23.8 & 23.8 & 25.2 & 26.6 & 25.4 & 0.2 \\
\hline Second cut & 77.4 & 76.4 & 92.6 & 76.1 & 74.0 & 0.9 \\
\hline Third cut & 14.6 & 9.2 & 11.0 & 12.1 & 11.3 & 1.1 \\
\hline Fourth cut & 9.2 & 1.8 & 43.4 & 19.8 & 18.9 & 3.6 \\
\hline \multicolumn{7}{|c|}{ Average temperature, ${ }^{\circ} \mathrm{C}$} \\
\hline First cut & 18.3 & 18.4 & 19.4 & 18.4 & 19.2 & 0.3 \\
\hline Second cut & 20.3 & 21.5 & 22.4 & 20.9 & 22.3 & 0.5 \\
\hline Third cut & 22.5 & 24.5 & 25.4 & 23.8 & 24.6 & 0.6 \\
\hline Fourth cut & 25.8 & 25.9 & 22.0 & 24.5 & 26.1 & 0.8 \\
\hline
\end{tabular}

${ }^{1}$ PreB-21dd $=21$-d cutting interval, prebloom; FrsB-28dd $=28$-d cutting interval, first bloom; FulB-35dd = 35-d cutting interval, full bloom.

$2.0 \%$, respectively; SEM $=0.83)$. The NPN and soluble protein concentrations also were different between the 21 - and the 28- or 35-d harvest intervals $(P<0.01)$. These results indicate that maturity influenced both the concentration and solubility of alfalfa protein. No differences $(P=0.12)$ were observed for detergentinsoluble proteins (acid detergent-insoluble protein or neutral detergent-insoluble protein), suggesting that harvest interval had little effect on these fractions. When expressed on a DM basis, Elizalde et al. (1999a) reported similar changes with age in soluble $\mathrm{CP}$ and NPN for alfalfa. In a companion paper (Elizalde et al., 1999b), they observed that immature alfalfa contained more ruminal degradable protein than mature alfalfa. Thus, the small changes in protein solubility we observed for alfalfa of similar age to those of Elizalde et al. (1999a,b) may have affected their ruminal degradation. Protein content or composition was not influenced by the year of the trial.

Results regarding the fiber fraction are reported in Table 5. No differences $(P=0.11)$ were observed for $\mathrm{NDF}$ or ADF $[41.0 \pm 4.1,40.4 \pm 2.7$, and $41.32 \pm 4.3 \%$ $\mathrm{NDF}(\mathrm{SEM}=1.35)$ and $30.25 \pm 2.0,30.68 \pm 1.4,31.15$ $\pm 2.3 \mathrm{ADF}(\mathrm{SEM}=1.02)$ for the PreB-21dd, FrsB28dd, and FulB-35dd treatments, respectively). Acid detergent lignin was lower for the 21-d harvest interval $(P<0.01)$ compared with the 28 - and $35-\mathrm{d}$ intervals
$(6.3 \pm 0.8,6.9 \pm 0.5$, and $7.3 \pm 0.9 \%$, respectively; $\mathrm{SEM}=0.39)$. Lignification is an irreversible process, and this compound tends to decrease the amount and the surface of cell walls available for microbial attachment and digestion (Åman and Nordkvist, 1983). Considering this fact, it is possible to assess, according to Jung and Engels (2002), that the presence of lignin is critical to the potential degradation of cell walls, but its concentration alone may not explain completely these differences, as increased maturity would affect the portion of potentially digestible fibrous components linked to lignin. As for the protein fractions, even fiber amount and composition were not affected by year of the trial.

\section{Fiber Digestibility and Predicted Animal Response}

The in vitro estimation of NDF digestibility at $24 \mathrm{~h}$ confirms what was expected in that it decreased with maturity (Table 6); the in vitro NDF digestibility at $24 \mathrm{~h}$ of alfalfa harvested every $21 \mathrm{~d}(44.0 \pm 2.6 \%)$ differed $(P<0.01)$ with forages grown for $28(37.8 \pm$ $1.8 \%)$ or $35 \mathrm{~d}(34.1 \pm 2.8 \%)$. Considering the $240-\mathrm{h}$ in vitro NDF digestibility and thus the amount of NDF that is indigestible, it is possible to observe statistical differences $(P<0.01)$ due to different maturity levels. A lower amount of iNDF appeared within PreB-21dd $(15.5 \pm 0.9 \%)$ than in other treatments $(17.2 \pm 1.2$ and

Table 4. Moisture content of the harvested fresh alfalfa

\begin{tabular}{lccccccc}
\hline & \multicolumn{3}{c}{ Treatment $^{1}$} & & \multicolumn{3}{c}{ Year } \\
\cline { 2 - 3 } Moisture, \% & PreB-21dd & FrsB-28dd & FulB-35dd & & 2011 & 2012 & \multirow{2}{*}{ SEM } \\
\hline First cut & 75.2 & 75.9 & 73.8 & & 75.3 & 74.3 & 0.21 \\
Second cut & 72.9 & 71.0 & 65.3 & & 72.2 & 69.5 & 2.59 \\
Third cut & 65.3 & 58.3 & 55.8 & & 60.5 & 59.4 & 1.21 \\
Fourth cut & 59.0 & 55.3 & 70.6 & & 60.0 & 55.3 & 5.87 \\
\hline PreB-21dd = 21-d cutting interval, prebloom; FrsB-28dd = 28-d cutting interval, first bloom; FulB-35dd = \\
35-d cutting interval, full bloom.
\end{tabular}


Table 5. Chemical composition of the harvested alfalfa

\begin{tabular}{|c|c|c|c|c|c|c|}
\hline \multirow{2}{*}{$\begin{array}{l}\text { Chemical } \\
\text { composition, }{ }^{1} \\
\% \text { of DM }\end{array}$} & \multicolumn{3}{|c|}{ Treatment $^{2}$} & \multicolumn{2}{|c|}{ Year } & \multirow[b]{2}{*}{ SEM } \\
\hline & PreB-21dd & FrsB-28dd & FulB-35dd & 2011 & 2012 & \\
\hline$\overline{\mathrm{CP}}$ & $20.8^{\mathrm{A}}$ & $17.3^{\mathrm{B}}$ & $17.0^{\mathrm{B}}$ & 18.3 & 17.6 & 0.83 \\
\hline SolP & $6.3^{\mathrm{A}}$ & $4.4^{\mathrm{B}}$ & $4.9^{\mathrm{B}}$ & 5.5 & 4.8 & 0.23 \\
\hline NPN & $5.3^{\mathrm{A}}$ & $3.5^{\mathrm{B}}$ & $3.9^{\mathrm{B}}$ & 4.3 & 3.9 & 0.30 \\
\hline NDIP & 5.2 & 4.3 & 4.7 & 4.8 & 4.7 & 0.61 \\
\hline ADIP & 1.5 & 1.3 & 1.6 & 1.5 & 1.4 & 0.03 \\
\hline aNDF & 41.0 & 40.4 & 41.3 & 40.8 & 41.4 & 1.35 \\
\hline $\mathrm{ADF}$ & 32.3 & 31.6 & 31.5 & 31.3 & 31.6 & 1.02 \\
\hline ADL & $6.3^{\mathrm{b}}$ & $6.9^{\mathrm{a}}$ & $7.3^{\mathrm{a}}$ & 6.8 & 7.0 & 0.39 \\
\hline \multicolumn{7}{|c|}{$\overline{\mathrm{A}, \mathrm{B}}$ Means within a row with different capital letter superscripts differ $(P<0.01)$} \\
\hline \multicolumn{7}{|c|}{ a,b Means within a row with different lowercase letter superscripts differ $(P<0.05)$. } \\
\hline \multicolumn{7}{|c|}{$\begin{array}{l}{ }^{1} \mathrm{SolP}=\text { soluble protein } ; \mathrm{NDIP}=\text { neutral detergent-insoluble protein; ADIP }=\text { acid detergent-insoluble protei } \\
\text { aNDF }=\text { amylase- and sodium sulfite-treated NDF. }\end{array}$} \\
\hline \multicolumn{7}{|c|}{$\begin{array}{l}{ }^{2} \text { PreB- } 21 \mathrm{dd}=21-\mathrm{d} \text { cutting interval, prebloom; FrsB-28dd }=28-\mathrm{d} \text { cutting interval, first bloom; FulB-35dd } \\
35 \text { - } \mathrm{d} \text { cutting interval, full bloom. }\end{array}$} \\
\hline
\end{tabular}

$18.3 \pm 1.1 \%$ for FrsB-28dd and FulB-35dd treatments, respectively; $P<0.01$ ). With a similar NDF content among plots, this effect could be due to differences in ADL content. But again, iNDF data are far from being dependent on just the ADL values, indicating the ability of this compound to embed other cell wall components, compromising their potential digestion. Moreover, the ratio between iNDF and ADL appeared to be different than the ratio of 2.4 used in the CNCPSbased models $(2.46 \pm 0.05,2.57 \pm 0.08$, and $2.58 \pm 0.08$ for PreB-21dd, FrsB-28dd, and FulB-35dd treatments, respectively). Other authors (Cherney et al., 1993; Traxler et al., 1998) observed the same trend in iNDF amount related to plant maturity for perennial forages, but not for alfalfa, as is presented in the current study.

Once tested with CPM, the 3 treatments strongly influenced dietary RDP percentage (11.15, 9.99, and 9.88\% for PreB-21dd, FrsB-28dd, and FulB-35dd treatments, respectively) without any major difference in $\mathrm{NE}_{\mathrm{L}}$, expressed as megacalories per kilogram (1.67, 1.64, and $1.62 \mathrm{Mcal} / \mathrm{kg}$ for PreB-21dd, FrsB-28dd, and FulB-35dd treatments, respectively). According to other authors (Llamas-Lamas and Combs, 1990; Allen and Oba, 1998), a greater effect could be expected for animal productive performances. In terms of $\mathrm{ME}$ and MP, among PreB-21dd and FulB-35dd treatments, a difference of $1.4(\mathrm{ME})$ and $2.8(\mathrm{MP}) \mathrm{kg}$ of milk/d would be predicted. These results were obtained with equations that still consider the iNDF as ADL $\times 2.4$ because CPM currently does not allow input of iNDF values. Nevertheless, we suggest that implementation of such software should prove useful to increase the accuracy of evaluating the nutritional characteristics of forages.

\section{CONCLUSIONS}

Maturity influences both the protein and fiber fractions in alfalfa hay, but has its greatest effect on digestibility. Although in this study we tested only one alfalfa variety, not focusing on possible genetic effects, we observed that the maximum extent of digestion differed among treatments, with the indigestible fraction of fiber increasing with maturity, resulting in differ-

Table 6. In vitro NDF digestibility and rates of digestion of the harvested alfalfa

\begin{tabular}{|c|c|c|c|c|c|c|}
\hline \multirow[b]{2}{*}{ Measure $^{1}$} & \multicolumn{3}{|c|}{ Treatment $^{2}$} & \multicolumn{2}{|c|}{ Year } & \multirow[b]{2}{*}{ SEM } \\
\hline & PreB-21dd & FrsB-28dd & FulB-35dd & 2011 & 2012 & \\
\hline \multicolumn{7}{|c|}{ NDF digestibility, $\%$ of NDF } \\
\hline IVNDFD $(24 \mathrm{~h})$ & $44.0^{\mathrm{a}}$ & $37.8^{\mathrm{b}}$ & $34.0^{\mathrm{b}}$ & 39.1 & 38.4 & 1.18 \\
\hline IVNDFD (240h) & $62.2^{\mathrm{a}}$ & $57.5^{\mathrm{b}}$ & $55.7^{\mathrm{b}}$ & 58.9 & 58.1 & 1.07 \\
\hline iNDF, $\%$ of $\mathrm{DM}$ & $15.5^{\mathrm{b}}$ & $17.2^{\mathrm{a}}$ & $18.3^{\mathrm{a}}$ & 16.7 & 17.5 & 0.91 \\
\hline iNDF/ADL & 2.46 & 2.57 & 2.58 & 2.46 & 2.51 & 0.02 \\
\hline
\end{tabular}

a,b Means within a row with different superscript letters differ $(P<0.01)$.

${ }^{1}$ IVNDFD $=$ in vitro NDF digestibility; iNDF $=$ indigestible NDF.

${ }^{2}$ PreB-21dd $=21$ - $\mathrm{d}$ cutting interval, prebloom; FrsB-28dd $=28$ - $\mathrm{d}$ cutting interval, first bloom; FulB-35dd = 35-d cutting interval, full bloom. 
ent ratios of lignin in iNDF. This effect needs to be considered and implemented into the modern rationcalculating software in order to formulate an optimal diet from different alfalfa hays. Moreover, considering that biological determination of iNDF requires a significant amount of time and chemicals, availability of faster and accurate tools could be extremely useful to predict this fraction.

\section{REFERENCES}

Akin, D. E. 1989. Histological and physical factors affecting digestibility of forages. Agron. J. 81:17-25. http://dx.doi.org/10.2134/ agronj1989.00021962008100010004.

Albrecht, K. A., W. F. Wedin, and D. R. Buxton. 1987. Cell-wall composition and digestibility of alfalfa stems and leaves. Crop Sci. 27:735-741. http://dx.doi.org/10.2135/cropsci1987.001118 3X002700040027.

Allen, M. S., and M. Oba. 1998. Digestibility of forage fiber-Variation, measurements, and relationship to animal performance. Pages 125-138 in Proc. Western Canadian Dairy Seminar, Advances in Dairy Technology. Univ. Alberta, Edmonton, AB, Canada.

Åman, P., and E. Nordkvist. 1983. Chemical composition and in-vitro degradability of major chemical constituents of red clover harvested at different stages of maturity. J. Sci. Food Agric. 34:11851189.

AOAC (Association of Official Analytical Chemists). 1990. Official Methods of Analysis. 15th ed. AOAC, Arlington, VA.

Boston, R. C., D. G. Fox, C. J. Sniffen, R. Janczewski, R. Munson, and W. Chalupa. 2000. The conversion of a scientific model describing dairy cow nutrition and production to an industry tool The CPM Dairy project. Pages 361-377 in Modelling Nutrient Utilization in Farm Animals. J. P. McNamara, J. France, and D. Beever, ed. CABI Publishing, Oxford, UK.

Buxton, D. R., and M. R. Brasche. 1991. Digestibility of structural carbohydrates in cool-season grass and legume forages. Crop Sci. 31:1338-1345

Buxton, D. R., and J. R. Russell. 1988. Lignin constituents and cellwall digestibility of grass and legume stems. Crop Sci. 28:553-558.

Chandler, J. A. 1980. Predicting methane fermentation biodegradability. MS Thesis. Cornell Univ., Ithaca, NY.

Cherney, D. J. R., J. H. Cherney, and R. F. Lucey. 1993. In vitro digestion kinetics and quality of perennial grasses as influenced by forage maturity. J. Dairy Sci. 76:790-797.

Cox, W. J., J. H. Cherney, R. D. Pardee, and D. J. R. Cherney. 1994 Forage quality and harvest index of corn hybrids under different growing conditions. Agron. J. 86:277-282.

Elizalde, J. C., N. R. Merchen, and D. B. Faulkner. 1999a. Fractionation of fiber and crude protein in fresh forages during the spring growth. J. Anim. Sci. 77:476-484.

Elizalde, J. C., N. R. Merchen, and D. B. Faulkner. 1999b. In situ dry matter and crude protein degradation of fresh forages during the spring growth. J. Dairy Sci. 82:1978-1990.

Goering, H. K., and P. J. Van Soest. 1970. Forage Fiber Analyses (Apparatus, Reagents, Procedures, and Some Applications). Agricultural Handbook No. 379. USDA Agricultural Research Service, Washington, DC

Griffin, T. S., K. A. Cassida, O. B. Hesterman, and S. R. Rust. 1994 Alfalfa maturity and cultivar effects on chemical and in situ estimates of protein degradability. Crop Sci. 34:1654-1661.

Jung, H. G., and M. S. Allen. 1995. Characteristics of plant cell walls affecting intake and digestibility of forages by ruminants. J. Anim. Sci. $73: 2774-2790$
Jung, H. G., and F. M. Engels. 2002. Alfalfa stem tissues: Cell wall deposition, composition, and degradability. Crop Sci. 42:524-534.

Licitra, G., T. M. Hernandez, and P. J. Van Soest. 1996. Standardization of procedures for nitrogen fractionation of ruminant feeds. Anim. Feed Sci. Technol. 57:347-358.

Llamas-Lamas, G., and D. K. Combs. 1990. Effect of alfalfa maturity on fiber utilization by high producing dairy cows. J. Dairy Sci. 73:1069-1080.

Mathison, R. D., C. C. Sheaffer, D. L. Rabas, D. R. Swanson, and J. H. Halgerson. 1996. Early spring clipping and herbicide treatments delay alfalfa maturity. J. Prod. Agric. 9:505-509.

Mertens, D. R. 2002. Gravimetric determination of amylase-treated neutral detergent fiber in feeds with refluxing in beakers or crucibles: Collaborative study. J. AOAC Int. 85:1217-1240.

Minson, D. J., and M. N. McLeod. 1970. The digestibility of temperate and tropical grasses. Page 719 in Proc. XI Int. Grassland Congress. Surfers Paradise, Queensland, Australia. Tropical Grassland Society of Australia, St. Lucia, QLD, Australia.

Nordkvist, E., and P. Åman. 1986. Changes during growth in anatomical and chemical composition and in-vitro degradability of lucerne. J. Sci. Food Agric. 37:1-7.

Parmigiano-Reggiano Cheese Consortium. 2011. Manual of Consorzio del Formaggio Parmigiano-Reggiano. Accessed Jul. 7, 2014 http://www.parmigianoreggiano.com/consortium/rules_regulation_2/default.aspx.

Robertson, J. B., and P. J. Van Soest. 1981. The detergent system of analysis and its application to human foods. Pages 123-158 in The Analysis of Dietary Fiber in Foods. W. P. T. James and O. Theander, ed. Marcel Dekker, New York, NY.

Sewalt, V. J. H., W. G. Glasser, and K. A. Beauchemin. 1997a. Lignin impact on fiber degradation. 3. Reversal of inhibition of enzymatic hydrolysis by chemical modification of lignin and by additives. J. Agric. Food Chem. 45:1823-1828.

Sewalt, V. J. H., W. Ni, H. G. Jung, and R. A. Dixon. 1997b. Lignin impact on fiber degradation: Increased enzymatic digestibility of genetically engineered tobacco (Nicotiana tabacum) stems reduced in lignin content. J. Agric. Food Chem. 45:1977-1983.

Sniffen, C. J., J. D. O'Connor, P. J. Van Soest, D. G. Fox, and J. B. Russell. 1992. A net carbohydrate and protein system for evaluating cattle diets: II. Carbohydrate and protein availability. J. Anim. Sci. 70:3562-3577.

Tilley, J. M. A., and R. A. Terry. 1963. A two-stage technique for the in vitro digestion of forage crops. J. Br. Grassl. Soc. 18:104-111. http://dx.doi.org/10.1111/j.1365-2494.1963.tb00335.

Traxler, M. J., D. G. Fox, P. J. Van Soest, A. N. Nell, C. E. Lascano, D. P. D. Lanna, J. E. Moore, R. P. Lana, M. Vélez, and A. Flores. 1998. Predicting forage indigestible NDF from lignin concentration. J. Anim. Sci. 76:1469-1480.

Van Soest, P. J. 1994. Nutritional Ecology of the Ruminant. 2nd ed. Cornell University Press, Ithaca, NY.

Van Soest, P. J., M. E. Van Amburgh, J. B. Robertson, and W. F. Knaus. 2005. Validation of the 2.4 times lignin factor for ultimate extent of NDF digestion, and curve peeling rate of fermentation curves into pools. Pages 139-150 in Proc. Cornell Nutrition Conference, Syracuse, NY. Departments of Animal Science and Poultry Science, Cornell University, Ithaca, NY.

Weir, W. C., L. G. Jones, and J. H. Meyer. 1960. Effect of cutting interval and stage of maturity on the digestibility and yield of alfalfa. J. Anim. Sci. 19:5-19.

Yu, P., D. A. Christensen, J. J. McKinnon, and J. D. Markert. 2003. Effect of variety and maturity stage on chemical composition, carbohydrate and protein subfractions, in vitro rumen degradability and energy values of timothy and alfalfa. Can. J. Anim. Sci $83: 279-290$. 